\title{
Evidensbevægelsens spredning til biblioteker i Danmark, Norge og Sverige
}

\author{
Af Carl Gustav Johannsen
}

\begin{abstract}
Artiklen søger med afscet i Røviks teori om konceptmigration at identificere og forklare mønstre for spredning og udbredelse af evidensbevagelsens begreber og praksisser i biblioteker i Danmark, Norge og Sverige. For alle tre lande gør sig store forskelle galdende i forhold til bibliotekstyper, hvor forskningsbiblioteker $i$ almindelighed og medicinske biblioteker $i$ scerdeleshed er langt mere involverede og aktive $i$ evidensbevagelsen end folkebibliotekerne $i$ de tre lande. Sammenligner vi de tre lande indbyrdes er det oplagt, at Sverige er det land, hvor evidensbevagelsen i bibliotekssammenhoenge slog tidligst og mest synligt igennem. I Norge har der også de senere år varet en voksende interesse for evidens, hvilket bl.a. er kommet til udtryk gennem en raeke målrettede uddannelses- og efteruddannelsestilbud. En faktor som utvivlsomt har hommet evidenskonceptets udbredelse har varet oversattelsesproblemer fra en naturvidenskabelig medicinsk sammenhoeng til blødere, mere humanistiske og samfundsfagligt orienterede biblioteksmiljøer. En sammenligning med $f x$ den meget hurtige immigration og spredning af loeringskonceptet 23 ting fra amerikanske biblioteker til biblioteker i Danmark og mange andre lande kan illustrere den barriere som ligger i dekontekstualisering og kontekstualisering af et koncept.
\end{abstract}

Carl Gustav Johannsen er cand.mag., ph.d. og lektor ved Det Informationsvidenskabelige Akademi. cgj@iva.dk

\section{Indledning}

Formålet med denne artikel er at præsentere et overblik over evidensbaseret praksis (EBP) i Norden (Danmark, Norge og Sverige). Indledningsvist vil valget af Røviks teori om konceptmigration som teoretisk bagtæppe blive begrundet. Herefter beskrives og vurderes, hvilken gennemslagskraft evidensbevægelsen har haft i Norden. Her vil analysen i høj grad være inspireret af Røviks tilgang og begrebsapparat, ligesom forskelle og ligheder mellem udviklingen i de tre lande vil blive fremhævet. Endelig vil der gennem en sammenligning med et aktuelt, succesrigt importeret bibliotekskoncept - det amerikanske "23 ting" koncept for efteruddannelse i sociale teknologier på Internettet - blive foretaget en analyse af mulige forklaringer på evidenskonceptets svage eller helt manglende gennemslagskraft i forhold til bibliotekssektoren i Norden.

Artiklen er en oversigtsartikel, der på den ene side peger på fremtidige forskningsområder og på den anden side fungerer som en perspektivering af flere af artiklerne i dette temanummer af tidsskriftet Dansk Biblioteksforskning. Artiklen belyser tre temaer. Det første tema vedrører karakteristika ved adoption og implementering af evidenskonceptet i BDI-sektoren i Norden. Det andet tema vedrører omfanget af gennemslagskraften og mulige forklaringer herpå, og endelig vil det tredje tema belyse og diskutere forskelle mellem de nordiske lande vedrørende evidensbegrebet i forhold til biblioteker. 


\section{Centrale begreber}

EBP i biblioteker i almindelighed og i de nordiske folke- og forskningsbiblioteker i særdeleshed kan forstås inden for rammerne af begrebet konceptmigration, som en betegnelse for det forhold, at ideer og koncepter krydser grænser og bevæger sig fra land til land, fra profession til profession og fra kontekst til kontekst. Evidensprincipperne har således siden slutningen af 1990'erne bevæget sig fra lægevidenskaben til biblioteksvæsnet og fra engelske og amerikanske medicinske biblioteker - formidlet af skikkelser som englænderen Andrew Booth og amerikaneren Jonathan Eldredge (Alopaeus, 2001) - til biblioteker i Danmark, Norge og Sverige. For at nuancere problemstillingen kan vi indføre en skelnen mellem ideernes tilbudsside og deres overførelses- og modtagerside, samt en yderligere opdeling mellem tre hovedelementer: 1) aktørerne, 2) produkterne, der er de ideer og opskrifter som udvikles og 3 ) de grundlæggende antagelser hos aktørerne om markedet for de pågældende ideer og opskrifter. Til det andet teoretiske hovedelement, overførelses- og modtagersiden, knytter sig et andet sæt af problemstillinger med fokus på, hvordan de enkelte opskrifter og ideer overføres, modtages, implementeres og udnyttes.

Begrebsdannelser omkring konceptmigration inviterer yderligere til flere interessante spørgsmål og problemstillinger: Hvilke aktører (udviklere, formidlere og autoritative instanser) har været og er aktuelt i spil i BDI-sektoren i relation EBP? Hvad karakteriserer de forestillinger om evidens som præsenteres og spredes på markedet? Hvilke sammenhænge er der mellem den form og det indhold, som ideerne har, og andre bredere sociale, økonomiske, teknologiske og kulturelle strømninger i tiden, herunder konkurrerende koncepter? Det kunne her fx handle om i hvilken udstrækning, evidensfilosofien er tidstypisk eller om den måske snarere repræsenterer en helt ny - eller for den sags skyld: forældet - tankegang.

Også i forhold til modtagersiden tilbyder tankegangen omkring konceptmigration tankevækkende synsvinkler og indsigter. Her kan vi operere med en anden central distinktion nemlig mellem to hovedtyper af konceptoversættelsesprocesser: dekontekstualisering og kontekstualisering. Ved dekontekstualisering forstås den proces, hvormed en bestemt praksis løsrives fra en given kontekst - in casu den medicin- ske - med henblik på overførsel til en anden kontekst - bibliotekerne. Dette sker typisk ved, at den konkrete praksis gøres mere abstrakt og almen. I forhold til evidens er dekontekstualiseringsbegrebet specielt relevant i forhold til, at evidenstankegangen oprindeligt blev udviklet i en medicinsk-lægevidenskabelig kontekst, hvorved der har været et udtalt behov for at gøre den mere almen og dermed anvendelig i andre fx biblioteksfaglige sammenhænge. Kontekstualisering handler omvendt om at konkretisere det gennem dekontekstualiseringen mere abstrakte koncept og materialisere det i forhold til den nye kontekst. I bibliotekssammenhænge handler det således om at oversætte og omsætte generelle principper om fx forskningsbasering af praksis til konkrete biblioteksrelevante praksisser, aktiviteter, rutiner, normer, strukturer etc.

\section{Adoption og implementering af EBP i biblioteker i Danmark, Norge og Sverige}

Både interviews med bibliotekarer fra Danmark, Norge og Sverige, artikler om EBP i nordiske biblioteksfaglige tidsskrifter og fire artikler i dette temanummer peger på, at vi skal tilbage til 2001 for at finde dokumentation for, at evidenstankegangen er blevet introduceret i BDI-sammenhænge (Alopaeus, 2001). Det er næppe tilfældigt, at det er svenske medicinske bibliotekarer, der er de første, der introducerer begrebet, selvom introduktionen ganske vist finder sted i det danske forskningsbibliotekstidssskrift, DF-Revy. Ydermere skal man lægge mærke til, at man fra starten anerkender, at Evidence Based Librarianship i "allra högsta grad inspirerats av Evidence Based Medicine och dess avknoppning Evidence Based Nursing, Evidence Based Health Care m fl" (Alopaeus, 2001, s. 13; Haglund, 2011). Skal vi yderligere pege på begivenheder, der på det pågældende tidspunkt i 2001 kan tænkes at have inspireret udviklingen i Norden, kan nævnes afholdelse af den første Evidence Based Librarianship konference i Sheffield i 2001. Sveriges centrale rolle understreges af, at den femte EBLIP konference i rækken fandt sted i 2009 i Stockholm, arrangeret af Karolinska Institutets Universitetsbibliotek. Her optrådte fem keynote speakere: den amerikanske biblioteksevidensguru, Jonathan Eldredge, englænderen, Sue McKnight, samt tre svenskere: Anita Mirijamdotter, Birgitta Olander og Ola Pilerot. Ud fra sammensætningen af de forskellige organisationskomiteer at dømme synes interessenterne i evidens i biblio- 
tekerne at være blevet betydeligt bredere, idet der optræder repræsentanter for andre forskningsbiblioteker end de medicinske og for enkelte folkebiblioteker, ligesom de nordiske bibliotekaruddannelser - fx i Borås, Lund, København - nu også er kommet på banen. Konferencen samlede i alt 163 deltagere. I de publicerede evalueringer finder man varierende vurderinger, hvoraf nogle konstaterer, at EBP stadig i overvejende grad er et anliggende for medicinske biblioteker, mens andre betoner konceptets relevans for alle biblioteker (www.blogs.kib.ki.se/eblip5/files/ evaluations). Udover forskningsbiblioteker og uddannelsesinstitutioner for bibliotekarer har den nationale biblioteksforening, Svensk Biblioteksförening, også været aktiv gennem produktion af en række forskningsoversigter i 2007 og 2008: "Så in i Norden efter - En jämförelse av nationell bibliotekspolitik i Danmark, Finland, Norge och Sverige" (2007), "Bibliotekarien och professionen - forskningsöversikt" (2008) og "Framgångsrikt, men förbisett - om bibliotekets betydelse för integration" (2008). Både forskningsoversigten om integration og om bibliotekarprofessionen bygger på en systematisk gennemgang og præsentation af forskningen inden for de to emneområder, og der refereres både til publicerede artikler og til upublicerede magisterafhandlinger.

Også i Norge synes evidensbevægelsen tidligt at slå rod - igen især inden for medicinske forskningsbiblioteker - med en omfattende og bred vifte af aktiviteter i form af kurser, seminarer, akkrediterede efteruddannelsesprogrammer og med institutionel forankring, som det fremgår af Nordheim's artikel i dette temanummer. Norge er vel det land i Norden som bedst kan sammenlignes med Sverige med hensyn til interesse for og implementering af EBP eller EBLIP. Det skal bemærkes, at man både i Norge og Sverige i en vis udstrækning synes at foretrække alternative betegnelser som hhv. kunnskapsbasert og erfarenhetsbaserat praksis. I Sverige er det dog mest i folkebibliotekssammenhænge, at erfaringsbaseret foretrækkes frem for EBP eller EBLIP, mens det i Norge både er forsknings- og folkebibliotekskredse, der benytter begrebet kundskabsbaseret frem for evidensbaseret. I begge lande lægger man vægt på en blødere tilgang til evidens, hvor praksiserfaringer ligestilles med forskningsbaseret evidens. Specielt i Sverige synes der i folkebibliotekskredse at være udtalte forbehold over for omfattende og systematiske kortlægninger, idet man mere ønsker at tage udgangspunkt i egne praksiserfaringer. Både i Stock- holm og Göteborg er der etableret ansvarsområder og stillinger på regionalt niveau inden for folkebiblioteksvæsnet med sigte på at anvende forskningsresultater i den daglige praksis. Inspiration hertil hentes dog mere hos læringsteoretikere som David A. Kolb (f. 1939) med fokus på erfaringsbaserede læringssystemer end hos Booth (interview med Malin Ôgland den 8. december 2010). Et andet karakteristisk træk ved udbredelsen af evidenstænkningen i forhold til de forskellige bibliotekstyper er, at interessen for EBLIP-tankegangen kommer fra forskningsbibliotekssektoren til de svenske folkebiblioteker relativt sent i 2008-2009 i forbindelse med afholdelsen af den 5. EBLIP-konference i 2009.

I sammenligning med Norge og Sverige synes udviklingen i Danmark mindre fremskreden. I publikationen "Folkebibliotekerne i vidensamfundet" udgivet af Styrelsen for Bibliotek og Medier (2010) anbefales det dog, at en proces der skal udbygge den "evidensbaserede viden om bibliotekernes effekt og om ønsker og behov hos bibliotekernes brugere og ikke-brugere" iværksættes. Sammenlignet med andre koncepter på rejse fx det amerikanske 23 ting (rettet mod personale- og brugerundervisning i web 2.0 sociale teknologier), der inden for et par år er blevet taget $\mathrm{i}$ anvendelse af et stort antal danske folkebiblioteker (Johannsen, 2011; Nielsen, 2008) synes gennemslagskraften for EBP i biblioteker langt svagere. Svaret på dette spørgsmål rummer antagelig en nøgle til, hvordan man fremme og udvikle EBP i bibliotekerne.

\section{Omfang og gennemslagskraft}

Hvad angår tidspunktet for, hvornår evidenskonceptet første gang præsenteres for biblioteksfolk i Norden skal vi tilbage til 2001, hvor vi i det danske DF Revy finder det første skriftlige vidnesbyrd om, at konceptet er adopteret af svenske forskningsbibliotekarer. Tidspunktet for konceptets gennembrud er det derimod vanskeligere at udtale sig om, fordi det afhænger af, hvordan man definerer et gennembrud. Opstiller vi fx et kriterium for, hvornår et koncept har haft sit gennembrud på baggrund af en sammenligning med et andet fagligt-professionelt koncept som "23 ting" udviklet i forbindelse med introduktionen af sociale teknologier vil det være problematisk at hævde, at der overhovedet har fundet noget gennembrud sted for EBP i nordiske biblioteker. På den anden side kan gennemførelse af en international 
konference om emnet også betegne et gennembrud, hvilket så betyder, at 2009, hvor den internationale EBLIP konference blev afholdt i Stockholm er året for EBP's gennembrud i Norden. Sammenligner vi de tre nordiske lande: Danmark, Norge og Sverige synes der belæg for den opfattelse, at nogle lande er langt længere fremme end andre (Munch Kristiansen, 2010, s. 20). Typisk er det Sverige og Norge, der betegnes som foregangslande, mens Danmark befinder sig på sidstepladsen. Hvad angår bibliotekstyper synes interessen markant størst blandt forskningsbibliotekerne, hvor især de medicinske biblioteker er i front. Dette mønster er meget lig det, vi finder i fx England, hvor det helt tydeligt er i de medicinske biblioteker, at evidenstænkningen er stærkest.

Det er interessant, at oprettelsen af evidensproducerende organisationer inden for de sociale og pædagogiske områder ikke har haft nogen nævneværdig afsmittende virkninger i forhold til BDI-sektoren i de nordiske lande. Hvad angår spørgsmålet om aktører varierer billedet fra land til land. I Sverige har den svenske biblioteksforening ved siden af store medicinske forskningsbiblioteker udgjort en aktiv kraft, hvorimod biblioteksforeningerne i Danmark og Norge har været mere tilbageholdende. I Danmark har biblioteksvæsenets nationale, statslige organ, Styrelsen for Bibliotek og Medier, i 2010 vist interesse for evidens, og i Norge nævnes forskningsbaseret praksis i statslige bibliotekspolitiske udmeldinger fra 2006. Norge er utvivlsomt det land, hvor EBP er slået mest igennem i forhold til uddannelse af bibliotekarer og informationsspecialister, idet både Høgskolen i Bergen og i Oslo i hhv. 2007 og 2008 har etableret målrettede uddannelses- og videreuddannelsestilbud på området. Lokalt i det enkelte bibliotek er der foregået aktiviteter i alle tre lande med tilknytning til EBP fx i retning af om at dokumentere anvendte praksisser og at "implementere EBLIP-tilgangen i hverdagen som en naturlig måde at træffe sine beslutninger på" (Munch Kristiansen, 2010, 21). Derimod synes ambitionerne om at levere eller producere hård evidens på linje og niveau med, hvad de evidensproducerende organisationer gør inden for sundheds-, social- og uddannelsessektoren ikke at være specielt fremtrædende i BDI-sektoren i Norden. Som allerede nævnt er forbindelsen mellem den svage udvikling af evidenskonceptet i de nordiske biblioteker og bredere sociale, økonomiske, teknologiske og kulturelle strømninger i tiden, herunder konkurrerende koncepter svær at dokumentere.
Traditionelle forskelle mellem folke- og forskningsbiblioteker kan delvis forklare, hvorfor oversættelsen af konceptet fra en forskningsbibliotekskontekst til en folkebibliotekskontekst kan forekomme problemfyldt. Derimod synes en antagelse om, at den manglende udbredelse skyldes en udbredt forestilling hos danske biblioteksledere om, at en satsning på evidens kan have en negativ effekt på et biblioteks kreative formåen og innovationsevne ikke at kunne bekræftes gennem interviews med udvalgte biblioteksledere og udviklingschefer ifølge Nordentofts artikel i dette temanummer. Omvendt kan interviews bekræfte, at evidensbevægelsens tilknytning til medicinske og naturvidenskabelige forskningsidealer kan udgøre en barriere i forhold til mere humanistisk orienterede folkebibliotekarer.

Skal vi mere specifikt forsøge at belyse årsagerne til, at evidensbevægelsen har haft en så relativ lille gennemslagskraft, kan det være interessant at sammenligne med mere succesrige koncepter. Jeg valgte her konceptet "23 ting", som fra 2008-2010 har haft en betydelig succes og stor udbredelse som efteruddannelseskoncept for bibliotekspersonalet, og som model for kursusvirksomhed rettet mod bibliotekernes brugere i almindelighed eller mod særlige segmenter som fx folkeskolelærere (Johannsen, 2009).

Flere forhold synes her at have haft indflydelse på den meget forskellige gennemslagskraft. Væsentlig er her, at "23 ting" oprindeligt er udviklet med henblik på biblioteker i USA, hvilket reducerer translationsproblemerne og -omkostningerne ganske betydeligt, især hvad angår behovet for at dekontekstualisere og kontekstualisere. Mere specifikt kan den meget forskellige gennemslagskraft tillige føres tilbage til den måde og specielt de aktører, der har stået for konceptimporten. Her har indflydelsesrige bibliotekslederes besøg i USA og direkte kontakt til "23 tings" grundlægger, Helen Bowers, utvivlsomt spillet en vigtig rolle. En anden forklaringsmodel inddrager begrebet den "brændende platform," når talen har drejet sig om forandring og motivation for forandring. Man kan ikke bare blive på en brændende olieplatform - forandring handler her om liv og død. Inden for sundhedsvæsnet er spørgsmålet om liv og død i høj grad nærværende. En medvirkende faktor har her også været Internettet, der i høj grad har gjort patienter selvhjulpne med hensyn til information om forskellige behandlingsmetoders og medikamenters virkning eller mangel på samme. Også inden for ud- 
dannelsessektoren kan man pege på brændende platforms lignende mekanismer. Pisa-undersøgelser og ambitiøse forældre har utvivlsomt lagt et pres på folkeskolerne og deres læreres evne til med videnskabelig evidens at dokumentere om anvendte metoder i undervisningen virker. Det er ikke sådan, at spørgsmålet om indsatsers virkning eller mangel på samme har været helt fraværende i debatten om bibliotekernes virksomhed. Spørgsmålet om nedlæggelse af filialer, samarbejde mellem skole- og folkebiblioteker, Borgerservice på bibliotekerne etc., ville oplagt kunne drøftes med afsæt i forskning om virkninger og effekter i forhold til brugsmønstre, låneradfærd, besøgstal, påvirkning af image, identitet etc. Dette er sket men kun i begrænset omfang, fordi mange aktuelle biblioteksdebatemner i højere grad opfattes og fortolkes som værdi- og kulturpolitiske spørgsmål frem for diskussioner om effektivitet og virkning.

\section{Forskelle}

Vedrørende temaet om hvilke forskelle der gør sig gældende mellem de tre lande med hensyn konceptmigrationen er billedet mere komplekst. Overordnet er der nok ingen tvivl om, at Sverige har været tidligst på banen og også har markeret sig stærkt med afholdelsen af den 5. EBLIP konference i Stockholm i 2009. Til gengæld synes nordmændene stærke med hensyn til at implementere EBP i uddannelses- og efteruddannelsessammenhænge. Hvad angår den markante forskel i engagement mellem forskningsog folkebiblioteker, er det vurderingen, at forskellen er lige stor i de tre lande, selvom svenskerne i 2008 og 2009 bestræbte sig på også at involvere folkebibliotekerne.

Selvom der er peget på mindre forskelle mellem de tre nordiske lande, der er behandlet i denne artikel, synes lighederne at være større end forskellene. Det er i høj grad den aktuelle konfiguration af et felt og et givet netværk, der er betydningsfuldt i forhold til adoptionen af et koncept. Lighederne er interessante, idet der synes at være en nordisk tænkning vedrørende evidens, der i meget stor udstrækning vægter den erfaringsbaserede viden og en pluralistisk metodisk tilgang til den forskning, der kan producere evidensresultater. Det er også et interessant fællestræk, at især folkebibliotekerne i de tre lande ikke synes at forholde sig systematisk til konceptet.
En række af de problemstillinger, der er rejst i denne artikel og som udspringer af temanummeret, vil blive undersøgt videre i kommende fremstillinger.

\section{Referencer}

Alopaeus, E (2001). Evidence Based Librarianship/ kunskapsbaserad biblioteksverksamhet / biblioteksverksamhet på vetenskaplig grund. DF-Revy, 24 . årg., nr. 1, 13-15.

Alopaeus, E \& Axelsson, E (2002). Evidence Based Librarianship - vägen till kunskapsbaserad biblioteksverksamhet. Ikoner, nr. 6, 34-36.

Alopaeus, E (2005). The reflective practitioner: an introduction to Evidence Based Librarianship (EAHIL workshop, Palermo, June 23-25)(9 powerpoints).

Audunson, R (2009). Fra synsing til kunnskapsbasert praksis. Bok og bibliotek, 76(2), 12-13.

Brice, A \& Hill, A (2004). A brief history of evidence-based practice. I: A. Booth and A. Brice (eds.). Evidence-based practice for information professionals - a handbook (s. 13-23). London: Facet Publishing,.

Gjersdal, A (2010). Kunnskapsbasert praksis i bibliotek. Bibliotekforum, Årg. 35, nr. 8, 22-25.

Gjestrum, L (2009). Kunnskapsbasert praksis. Bibliotekaren, Nr. 2, 18-19.

Haglund, L \& Herron, D (2008). Evidensbaserat biblioteksarbete som en metod att stimulera kompetensutveckling. Paper presenterat vid konferensen "Möteplats inför framtiden", den 15-16 oktober 2008 i Borås

Haglund, L \& Herron, D (2005). Tidskriftklubben - en metod som kan utveckla bibliotekariens förmåga till kritisk analytisk granskning. Infotrend, 60(3), 7179.

Johannsen, CG (2011). Sociale teknologier og web 2.0 som vidensmedier (in press)

Munch Kristiansen, H (2010). Fra formodning til viden. Revy, nr. 3, 33. årg., 20-21. 
Nielsen, HJ (2008). Social Technologies in Practice. Scandinavian Public Library Quarterly, nr. 41, 2, 14-15.

Røvik, KA (2007). Trender og translasjoner - Ideer som former det 21. århundrets organisasjon. Oslo: Universitetsforslaget.

Styrelsen for Bibliotek og Medier (2010). Folkebibliotekerne $i$ vidensamfundet - Rapport fra Udvalget om folkebibliotekerne $i$ vidensamfundet. København: Styrelsen for Bibliotek og Medier.
Svensk Biblioteksförening (2007). Sverige - så in $i$ Norden efter - En jämförelse av nationell bibliotekspolitik i Danmark, Finland, Norge og Sverige. Stockholm: Svensk Biblioteksförening.

Svensk Biblioteksförening (2008). Bibliotekarien och professionen - en förskningsöversikt. Stockholm: Svensk Biblioteksförening.

Svensk Biblioteksförening (2008). Framgångsrikt, men förbisett - om bibliotekets betydelse för integration. Stockholm: Svensk Biblioteksförening. 